\title{
GENETIC AND MORPHOLOGICAL VARIATION IN THE BULBOPHYLLUM EXALTATUM (ORCHIDACEAE) COMPLEX OCCURRING IN THE BRAZILIAN “CAMPOS RUPESTRES”: IMPLICATIONS FOR TAXONOMY AND BIOGEOGRAPHY
}

\author{
Patricia Luz Ribeiro ${ }^{1,3}$, E.L. Borba ${ }^{2}$, E.C. SMidT ${ }^{1}$, S.M. LAMBerT ${ }^{1}$, \\ A. Selbach-Schnadelbach ${ }^{1} \&$ C. VAN Der Berg ${ }^{1}$ \\ ${ }^{1}$ Universidade Estadual de Feira de Santana, Departamento de Ciências Biológicas, Laboratório de Sistemática \\ Molecular de Plantas, Rodovia BR116 Km 03, Feira de Santana, BA, 44031-460, Brazil and \\ 'Universidade Federal de Minas Gerais, Instituto de Ciências Biológicas, Departamento de Botânica, Avenida \\ Antônio Carlos 6627, Caixa Postal 486, Belo Horizonte, MG, 31270-901, Brazil \\ Author for correspondence: patyluzribeiro@yahoo.com.br
}

KEY Words: allozymes, Bulbophyllum exaltatum, Cadeia do Espinhaço, campo rupestre, genetic variability, geographic barrier

\section{Introduction}

Bulbophyllum Thouars is a pantropical genus. It is one of the most species-rich genera of the Orchidaceae, with ca. 1.200 species (Dressler 1993). The genus presents myophily (pollination by Diptera) as pollination syndrome. Because orchid species are mainly selfcompatible, we expect that fly-pollinated orchids present low variability within the populations and high genetic differentiation among conspecific populations, due to the reduction of the gene flow (Borba \& Semir 1998, Borba et al. 2001). This could help to explain the high number of species in genera of fly-pollinated orchids, most of them with restricted distribution.

High montane areas of the Southeastern and Northeastern regions of Brazil, mainly in the "campos rupestres" vegetation, are the habitat for a species complex within Bulbophyllum sect. Didactyle, in which traditionally ca. 15 rupicolous species were recognized. The species of this group are vegetative uniform, being separated exclusively by the floral morphology, mainly lip differences. The main taxonomic problem in this group is the delimitation of $B$. involutum, B. ipanemense, B. longispicatum, B. geraense and $B$. warmingianum.

In the present study, we carried out population genetic studies using isozyme markers in 601 individuals of 33 natural populations, in order to assess the genetic variation and degree of differentiation in some species belonging to this complex. We also performed a morphometric analysis in some of the individuals of the genetic study, using multivariate methods as an attempt to improve species delimitation. Vouchers for each population were deposited in the herbarium of the Universidade Estadual de Feira de Santana (HUEFS).

\section{Results and discussion}

The four species studied, considered a priori to be $B$. exaltatum, $B$. involutum, $B$. sanderianum and $B$. weddellii, displayed high genetic variation $\left(H_{\mathrm{e}} 0.086\right.$ - 0.404) and a high degree of genetic structure $\left(F_{\mathrm{ST}}\right.$ $0.145-0.269)$ which indicates restricted gene flow. The latter was detected only among populations of $B$. exaltatum, and is probably due to long-distance seed dispersion by wind. However, habitat fragmentation can be a factor even more important for the differentiation of these populations.

In the results of the isozyme analysis, none of the conspecific populations were formed a distinct cluster. Therefore, based on these data, a clear taxonomic delimitation among the four species considered is not possible within this complex. On the other hand, the populations clustered primarily based on the State of origin, which correspond to the two main disjunt areas of campos rupestres in Minas Gerais and Bahia (Fig. 1). The inversion of the relative frequency of the 


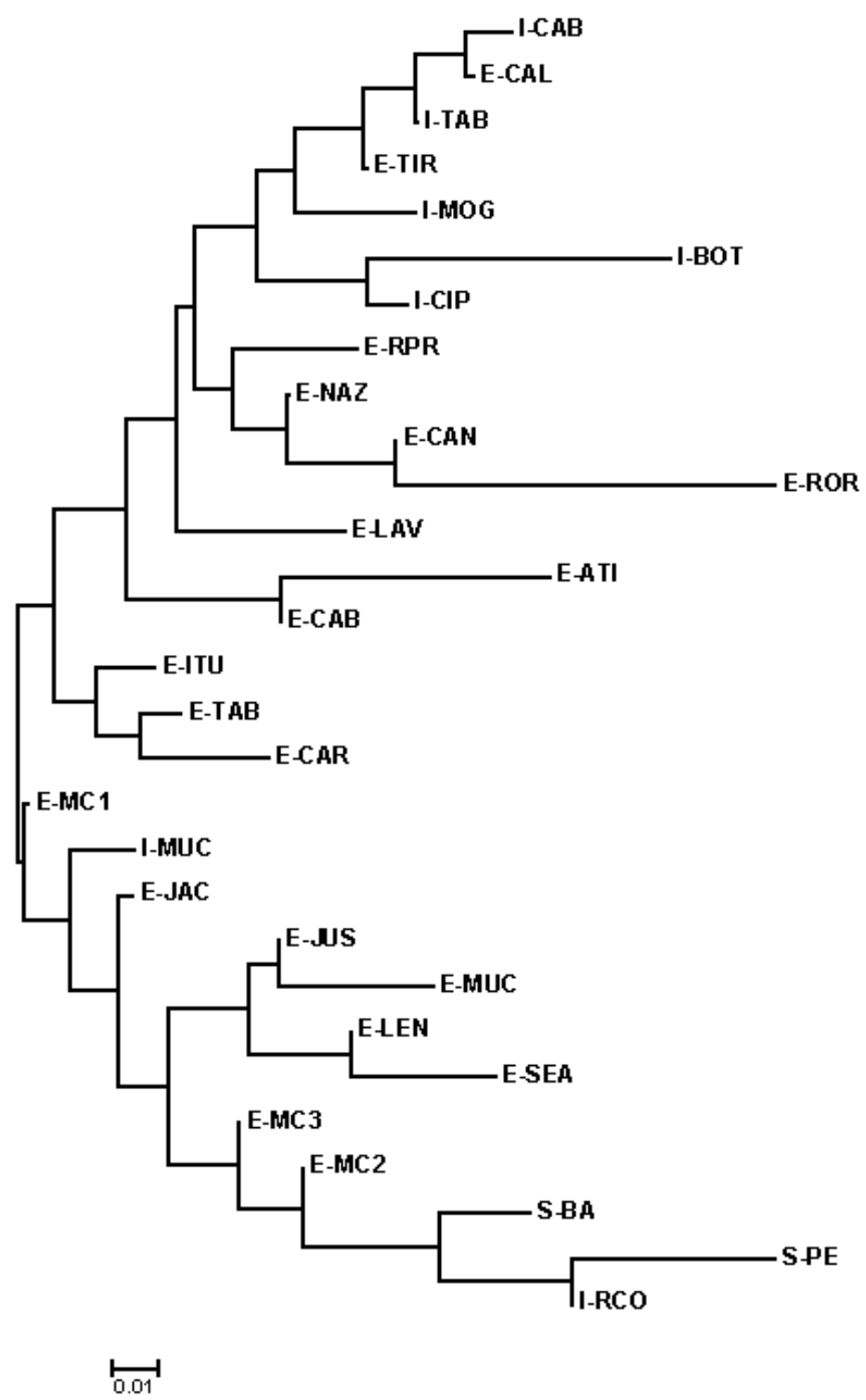

FIGURE 1. Neighbor-joining tree of 29 populations of B. sanderianum (S-) (two pops.), B. involutum (I-) (seven pops.) and B. exaltatum (E-) (20 pops.), based in nine allozymic loci and constructed using the matrix of Nei genetic distances (1978; unbiased genetic distance).

alleles of the locus MDH-1 is probably the main responsible factor for the separation of the two large groups of populations. The first group corresponds to the populations of the states of Bahia and Pernambuco, where the allele MDH-1 100 is most frequent (except for the population E-MC1 of Morro do Chapéu and I-MUC of Mucugê). The second is formed by the populations from São Paulo, Minas Gerais and Roraima States, where the allele 93 is the most frequent (Fig. 2) The genetic differentiation test $F_{\mathrm{ST}}$ based on ? confirms the important participation of this locus in the structuring of the populations for the separation. Perhaps, hybridization events and early differentiation among the taxa have contributed to maintain the high genetic identity among populations, thus generating the observed reticulate pattern of clustering among different species (Fig. 1).

Morphological data suggest that $B$. involutum popula- 


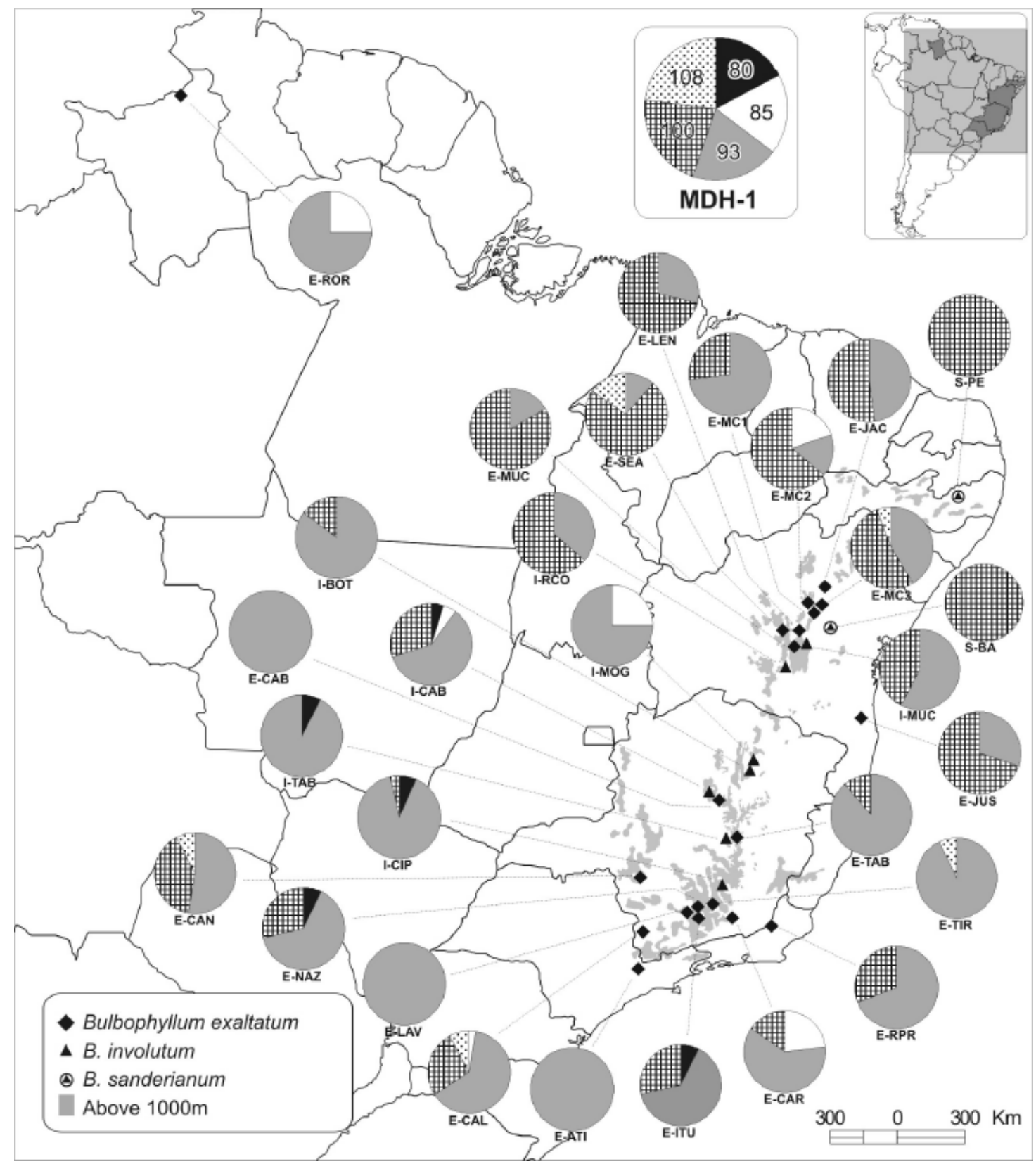

FIGURE 2. Graphic representation of the allele frequencies of the loci MDH-1 in populations of B. exaltatum (E-), B. involutum (I-) and B. sanderianum (S-) studied. Notice the inversion in the relative frequency of the alleles 93 and 100 among the populations from Minas Gerais and Bahia (except I-MUC e E-MC1).

tions in Minas Gerais stand out as a distinct taxon in relation to $B$. exaltatum. However, the populations of both taxa in Bahia State displayed lower differentiation (Fig. 3). In the first axis of the analysis (CVA) we observed more clearly the separation between the populations of $B$. exaltatum from Minas Gerais from Bahia and Roraima plus B. involutum, mainly for the smallest size of the lip and larger width of the dorsal sepal in the former. The second axis separates $B$. exaltatum from Bahia plus Roraima from $B$. involu- 


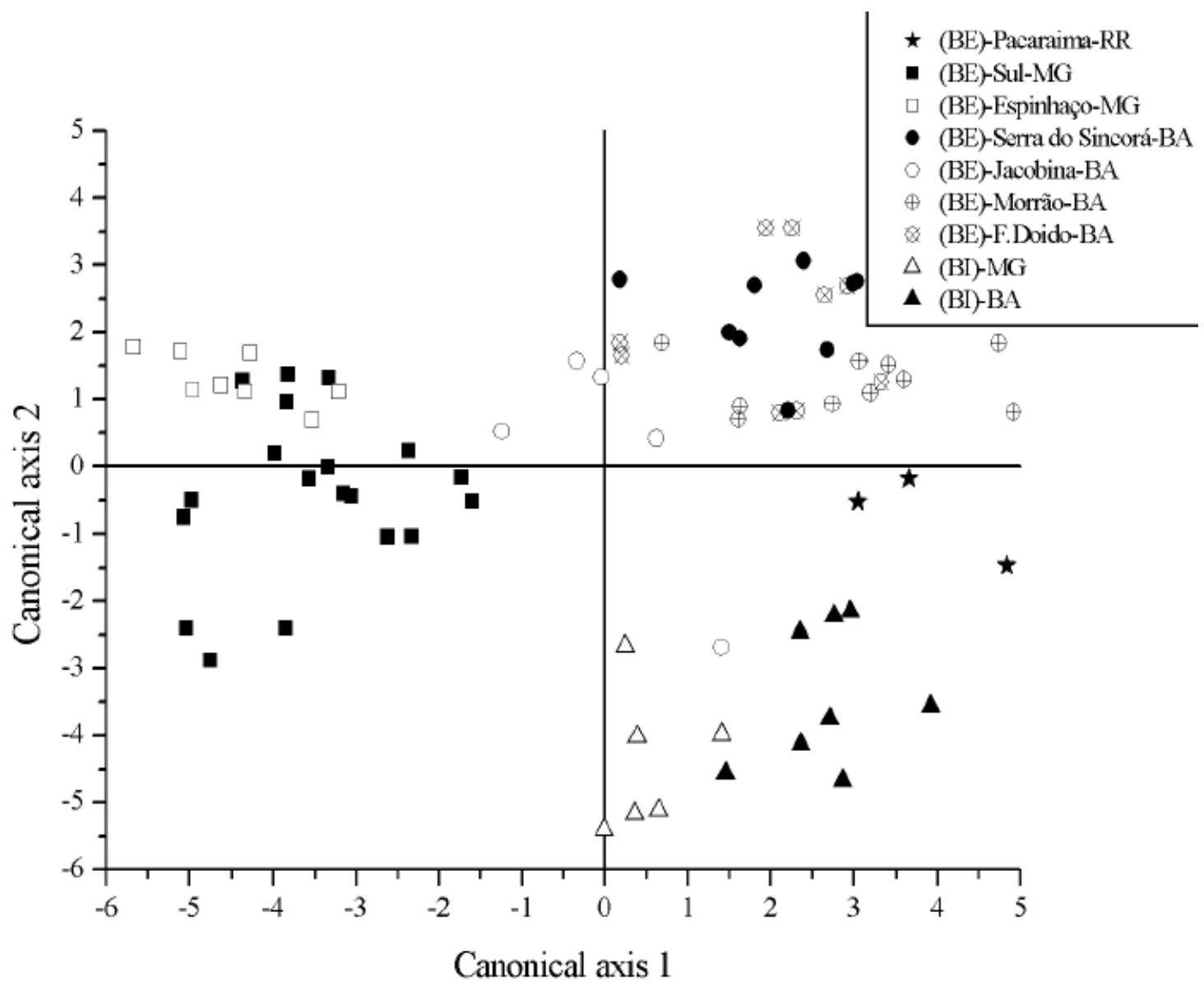

FIGURE 3. Graphic representation of the dispersion on the two first axes of the canonical analysis (CVA), based in 21 morphological characters, from individuals of nine groups of populations of $B$. involutum (BI) and B. exaltatum (BE) established a prior $i$ by geographical areas. Percentual of accumulated variation in the first two axes $=71 \%$ (axis $1=$ $47.3 \%$; axis $2=23.7 \%$ ).

tum. The canonical axes one and two accumulated respectively 47.3 and $23.7 \%$ of the variance.

Genetic and morphological data point out that the geographical barriers between Bahia and Minas Gerais, and the larger distance of the Roraima population suggest genetic and morphological differentiation between the populations from these States. The differentiation between the populations from Minas Gerais and the populations from Bahia apparently are related to the main separation of the Cadeia do Espinhaço in two portions. The northern portion is called Chapada Diamantina, and lies entirely in Bahia State, and the south includes the Planalto de Diamantina in Minas Gerais. This geographical sepa- ration is a north-south gap of $300 \mathrm{~km}$ with lowlands and has been considered as a strong geographical barrier to the migration of campo-rupestre plant species, with apparently great contribution in the differentiation of the plants in the campos rupestres from these areas (Giulietti \& Pirani 1988, Harley 1988). Several other disjunctions affecting the geographical distribution in this vegetation has frequently been associated to the genetic differentiation of populations in several groups of plants (Borba et al. 2001, Jesus et al. 2001, Lambert et al. 2006a, 2006b).

Based on genetic, morphological, and reproductive biology of these and other Bulbophyllum species studied, we can conclude that all of the populations 
considered B. exaltatum from Minas Gerais and São Paulo States should be treated taxonomically as a single entity, not divisible even in infraspecific categories. Bulbophyllum exaltatum is the oldest name to be applied to the populations from Minas Gerais, generally referred as $B$. warminginum, $B$. ipanemense or $B$. geraense in the literature, thus requiring new synonymies.

ACKNowledgments. We thank Ana C. S. Pereira and Ricardo V. Boas for fieldwork and technical support. This work was supported by a grant from the Fundação de Apoio à Pesquisa do Estado da Bahia (FAPESB). PLR received a schoolarship from CAPES. ELB and CVDB are supported by a grant (PQ2) from CNPq.

\section{LITERATURE CITED}

Borba, E.L. \& J. Semir. 1998. Wind-assisted fly pollination on three species of Bulbophyllum (Orchidaceae) occurring in the Brazilian campos rupestres. Lindleyana 13: 201-218.

Borba, E.L., J.M. Felix, V.N. Solferini \& J. Semir. 2001. Fly-pollinated Pleurothallis (Orchidaceae) species have high genetic variability: evidence from isozyme markers. Amer. J. Bot. 88: 419-428

Dressler, R.L. 1993. Phylogeny and classification of the orchid family. Portland: Dioscorides Press.

Giulietti, A.M \& J.R. Pirani. 1988. Patterns of geographic distribution of some plant species from the Espinhaço
Range, Minas Gerais and Bahia, Brazil. Pp. 36-69 in: P.E. Vanzolini \& W.R. Heyer (eds.). Proceedings of a Workshop on Neotropical Distribution Patterns. Rio de Janeiro: Academia Brasileira de Ciências.

Harley, R.M. 1988. Evolution and distribution of Eriope (Labiatae) and its relatives in Brazil. Pp. 71-120 in: P.E. Vanzolini \& W.R. Heyer (eds.). Proceedings of a Workshop on Neotropical Distribution Patterns. Rio de Janeiro: Academia Brasileira de Ciências.

Jesus, F.F., V.N. Solferini, J. Semir \& P.I. Prado. 2001. Local genetic differentiation in Proteopsis argentea (Asteraceae), a perennial herb endemic in Brazil. Pl. Syst. Evol. 226: 59-68.

Lambert, S.M., E.L. Borba, M.C. Machado \& S.C.S. Andrade. 2006a. Allozyme diversity and morphometrics of Melocactus paucispinus (Cactaceae) and evidence for hybridization with $M$. concinnus in the Chapada Diamantina, North-eastern Brazil. Ann. Bot. 97: 389403.

Lambert SM, Borba EL, Machado MC. 2006b. Allozyme diversity and morphometrics of the endangered Melocactus glaucescensMelocactus ?albicephalus.

Patricia Luz Ribeiro first worked with orchids for her undergraduate thesis in Biological Sciences (2001-2003), with the title "The genus Bulbophyllum in the Chapada Diamantina, Bahia, Brazil". Since then, she has been working in several projects, such as analysis of intra and inter populational genetic variation of endangered Cattleya and Sophronitis species from Northeastern of Brazil using allozime markers. During her Master of Science studies (2003-2006), she worked with the "Genetic and morphometric variation on populations of the Bulbophyllum exaltatum complex in the Brazilian campos rupestres", supervised by Dr. Eduardo Leite Borba, at the Feira de Santana State University, Bahia, Brazil. She is currently working on the development of DNA barcoding markers in Cattleya and Sophronits species, supervised by Dr. Cassio van den Berg. 
LANKESTERIANA 